\section{Preliminary Investigations on the Influence of Reserpine Therapy on Adrenocortical Function in Schizophrenia ${ }^{1}$}

HoAgLAND, Rinkei and HYDE ${ }^{2}$ studied the metabolic effects of the administration of lysergic acid diethylamide and ACTH to schizophrenic patients. They have discussed the biochemical aspects of schizophrenia in relation to adrenaline and serotonin metabolism, and the comparatively poor response of the adrenals of schizophrenic patients to stimulation by ACTH. KLINE ${ }^{3}$ has produced further evidence of the value of reserpine therapy in the symptomatic treatment of schizophrenia and other mental disorders. We have studied the urinary excretion of adrenal cortical steroids in 8 schizophrenic patients given graded doses of reserpine over a four-week period. The recently described rapid and simple method of Appleby, Gibson, Norymberski and Stubbs ${ }^{4}$ for the assessment of adrenocortical function has been used in these experiments. The method measures selectively the total 17-hydroxylated $\mathrm{C}_{21}$ adrenal steroids $(17-\mathrm{OH}$, K.G.S.). Since difficulty is encountered in collecting complete $24 \mathrm{~h}$ specimens of urine from mentally disturbed and overactive patients, we have expressed our results as 3 day average rations of urinary $17-\mathrm{OH}, \mathrm{K}$. G. S. to urinary creatinine.

The results are summarized in the Table.

The influence of reserpine therapy on urinary $17-\mathrm{OH}$, K.G.S./creatinine ratio in schizophrenic patients

\begin{tabular}{|c|c|c|c|c|}
\hline \multirow{3}{*}{ Patient } & \multicolumn{4}{|c|}{ Ratio of $17-\mathrm{OH}$, K.G.S./creatinine } \\
\hline & \multirow[b]{2}{*}{ No reserpine } & \multicolumn{3}{|c|}{ Dosage of reserpine } \\
\hline & & $\begin{array}{l}\text { after } 2 \text { wecks } \\
\text { therapy with } \\
\text { reserpine } \\
(\mathrm{x}-\mathrm{-1} \cdot 5 \mathrm{mg} / \text { day) }\end{array}$ & $\begin{array}{c}3^{\mathrm{rd}} \text { week } \\
(6 \mathrm{mg} / \mathrm{day})\end{array}$ & $\begin{array}{c}4^{\text {th }} \text { week } \\
\text { (9 mg/day) }\end{array}$ \\
\hline D.N. & $0 \cdot 0106$ & 0.0106 & - & 0.0103 \\
\hline F.L.* & $0 \cdot 0217$ & $0 \cdot 0110$ & - & 0.0140 \\
\hline F.R.* & $0 \cdot 012$ & 0.0085 & - & $0 \cdot 0080$ \\
\hline M.Y.* & $0 \cdot 017$ & 0.006 & - & 0.0203 \\
\hline P.H.* & $0 \cdot 0193$ & $0 \cdot 0110$ & - & 0.0101 \\
\hline R.N. & 0.0133 & 0.0100 & - & 0,0112 \\
\hline V.S.* & $0 \cdot 0360$ & 0.0100 & $\rightarrow$ & $0 \cdot 0160$ \\
\hline W.N. & $0 \cdot 0218$ & 0.0150 & - & $0 \cdot 0180$ \\
\hline
\end{tabular}

A statistical analysis of our results shows a significant reduction from the control values in the 3-day average ratios of urinary $17-\mathrm{OH}, \mathrm{K} . \mathrm{G} . \mathrm{S}$./creatinine at the $1-1 \cdot 5$ $\mathrm{mg}$ dosage level for reserpine $(P .=0 \cdot 02-0 \cdot 01)$. The results obtained at the fourth weak compared with the controls are not highly significant $(P=0.1-0.05)$ indicating that further studies at the higher dosage levels are required. Since there was individual clinical variation in response to the chronic dosage with reserpine, it

1 The authors wish to thank Professors J. ELkes and S. ZuckerMAN for their keen interest and support in this study. A. B. KAR is on deputation from the Central Drug Research Institute, Lucknow, India, under the Colombo Plan. The technical assistance of Miss Anne Overton and Miss Sieila Green is acknowledged.

2 H. Hoagland, M. Rinkel, and W. R. Hyoe, Arch. Neurol. Psychiat. 73, 100 (1955).

3 N. S. Kline, Ann. N. Y. Acad. Sci. 59, 107 (1954).

4 J. J. Appleby, G. Gibson, J. K. Norymberski, and R. D. StubBs, Biochem. J. 60,453 (1955). is not surprising to note a lack of uniformity regarding $17 \mathrm{OH}, \mathrm{K}$.G.S. excretion at this phase of the treatment. Our results show quite clearly that the lower dosage level of reserpine did not elicit stimulation of the pituitary adrenal axis. GaUnt, ReNzI, AnTonchaK, Miller, and Gilman ${ }^{5}$ showed that reserpine did not depress adrenal function in guinea pigs, but raised the question of the possibility of reserpine dampening the mechanism discharging ACTH in psychogenic stress.

Goodman, Florsheim, and Temperea ${ }^{6}$ have shown that after 25 days administration of reserpine, 11 out of 17 patients showed no eosinopenic response in the Thorn test. These results, while possibly indicating a reduced functional state of the hypothalamic-pituitary adrenal axis, should be accepted with reserve in view of the criticism of the eosinophil response test by TYLER, Migeon, and CASTLE? ${ }^{7}$. Furthermore, WINSOR ${ }^{8}$ has demonstrated a lack of influence of reserpine treatment $(0.5 \mathrm{mg}$ dosage levels) on the adrenocortical response in normals.

In unpublished work, Spanner, Ginzel, and BoscOTT, have confirmed some of the results of HoAGLAND et al. relating to the increased adrenocortical activity in response to lysergic acid diethylamide, but as indicated by $17-\mathrm{OH}$, K.G.S. excretion. Furthermore, agents which we have studied which block the psychogenic effects of L.S.D. depressed also the adrenocortical activity simultaneously. The possibility that the sedation induced by reserpine in schizophrenic patients, is linked with a reduced output of adrenocortical steroids must therefore be considered.

R. J. Boscott, M. Jeavons, and AMYA B. KAR

Departments of Anatomy and Experimental Psychiatry, The Medical School, University of Birmingham, December 21,1955 .

\section{Zusammenfassung}

Die Arbeit befasst sich mit der Harnausscheidung von Nebennierenrinden-Steroiden bei 8 schizophrenen Patienten vor und während der Behandlung mit allmählich ansteigenden Dosen von Reserpin. Eine statistisch nachweisbare Verringerung der Nebennierenrindenfunktion wurde während der Behandlung mit Reserpin beobachtet. Eine kritische Betrachtung dieser Ergebnisse wird vorgenommen.

5 R. Gaunt, A. A. Renzi, N. Antonchak, G. J. Miller, and M. Gilman, Ann. N. Y. Acad. Sci. 59, 22 (1954).

6 J. R. Goodman, W. H. Florsheim, and C. E. Tempereau, Proc. Soc. exper. Biol. Med. 90,196 (1955).

7 F. H. Tyler, C. Migeon, and H. CAstle, Endocrinology 8, 256 (1955).

8 T. Wrnsor, Ann. N. Y. Acad. Sci. 59, 61 (1954).

\section{The Anticancerous Action of 6-Azauracil(3,5-dioxo-2,3,4,5- tetrahydro-1,2,4-triazine)}

In the course of the last few years several analogs of the nucleic acids purine bases were tested in the chemotherapy of experimental neoplastic diseases. Some of these, e.g. 8-azaguanine and 6-mercaptopurine, have already found their application in clinical practice. 